\title{
Bio-Renewable Sources for Synthesis of Eco-Friendly Polyurethane Adhesives-Review
}

\author{
Ravindra V. Gadhave, Prakash A. Mahanwar, Pradeep T. Gadekar \\ Department Polymer and Surface Engineering, Institute of Chemical Technology, Mumbai, India \\ Email: ravi.gadhave3@gmail.com
}

How to cite this paper: Gadhave, R.V. Mahanwar, P.A. and Gadekar, P.T. (2017) Bio-Renewable Sources for Synthesis of EcoFriendly Polyurethane Adhesives-Review. Open Journal of Polymer Chemistry, 7, 57-75.

https://doi.org/10.4236/ojpchem.2017.74005

Received: March 25, 2017

Accepted: October 14, 2017

Published: October 17, 2017

Copyright $\odot 2017$ by authors and Scientific Research Publishing Inc. This work is licensed under the Creative Commons Attribution International License (CC BY 4.0).

http://creativecommons.org/licenses/by/4.0/

\begin{abstract}
Bio-renewable sources used during manufacturing of polyurethane (PU) adhesives have been used extensively from last few decades and replaced petrochemical based PU adhesive due to their lower environmental impact, easy availability, low cost and biodegradability. Bio-renewable sources, such as vegetable oils (like palm oil, castor oil, jatropha oil, soybean oil), lactic acid, potato starch and other bio-renewable sources, constitute a rich source for the synthesis of polyols which are being considered for the production of "eco-friendly" PU adhesives. Various bio-renewable sources for synthesis of bio-based PU adhesives and their potential applications are discussed in this review. This paper will focus on the progress of research in bio-based materials for adhesive application.
\end{abstract}

\section{Keywords}

Bio-Renewable, Polyol, Oil, Polyurethane, Adhesive

\section{Introduction}

Polyurethanes are up to date the most versatile polymers due to the flexibility of structure design at the application site. They are mainly used in footwear, packaging, automotive industry and furniture assembly in the form of rigid and flexible foams, coatings, adhesives, sealants, elastomers and binders. Increasing environmental awareness among producers and consumers has led to substantial interest and research in biomass resource stead of petrochemicals for PU synthesis [1]-[10].

Polyurethane as wood adhesives has developed a reputation for reliability and high performance [11] [12]. The performance and behavior of adhesive systems for wood depend on a wide range of variables, such as smoothness of substrate surfaces, $\mathrm{pH}$, presence of extractives, and grain direction [13]. The bonding 
mechanism of the adhesive to the wood substrate can include covalent bonding, weaker forces such as van der Waals forces and hydrogen bonding, or mechanical interlocking [14] [15]. Adhesives based on urea-formaldehyde, melamine formaldehyde, urea melamine formaldehyde and phenol-formaldehyde are commonly used [16] [17] [18], but are very sensitive to hydrolysis [19] [20] [21]. These adhesives also produce health hazards because of the formaldehyde they release [22]. To overcome such problems, scientists are trying to develop new polymeric adhesives [23] [24] [25]. PU adhesive has developed a reputation for reliability and high performance [25] [26].

An attempt has been made to develop PU adhesives that were at least partially made from the natural materials like natural vegetable oils [29]-[34], lignin, lactic acid and potato starch [27], and edible or non-edible plant-derived oils. Bio-renewable resources constitute a rich source of precursors for the synthesis of polyols and isocynates which are being considered for the production of "greener" PU adhesives [28] and reaction between polyol and isocynate is shown in Figure 1. Various bio-renewable sources for synthesis of bio-based PU adhesives and their potential applications are discussed in this review. This paper will focus on the progress of research in bio-renewable sources for adhesive application.

\section{Vegetable Oil Based Polyurethane Adhesive}

Polyurethanes are synthesized from vegetable oils obtained from various plant seeds such as castor, jatropha, palm, soybean etc [35]-[42]. Large quantity of plants oils are important renewable source to make soaps, surfactants, lubricants, diluents, plasticizers, inks, agrochemicals, composite materials, food industry etc. [43] [44] [45] [46]. The major components of vegetable oils are triglycerides which are esters of glycerol with three long chain fatty acids having varying composition depending on the source of oil [47]. Structure of triglyceride is shown in Figure 2. Polyols and polyisocyanates which are major raw materials for the synthesis of polyurethanes can be readily synthesized by utilizing these reactive sites [48]. Upon hydrolysis, triglycerides of vegetable oils give different fatty acids and glycerols. There are many factors which affect the properties of oil based coatings such as composition of various saturated and unsaturated fatty acids, extent of un-saturation, chain length of fatty acids, location and stereochemistry of the double bonds in fatty acid chains [49] [50]. Fatty acids can be a part of polyester polyols whereas hydroxyl functional vegetable oils are directly used in polyurethanes [51] [52] [53]. In past and present, various bio renewable PU are synthesized from vegetable oils as well as other bio renewable sources [54] [55] [56]-[93].

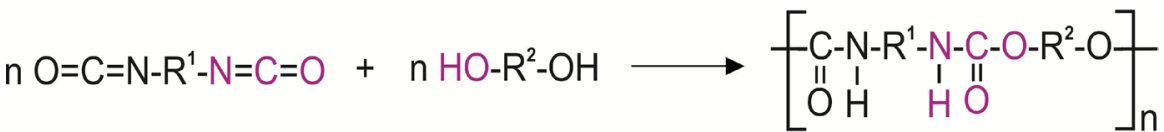

Figure 1. Reaction between polyisocynate and polyol. 


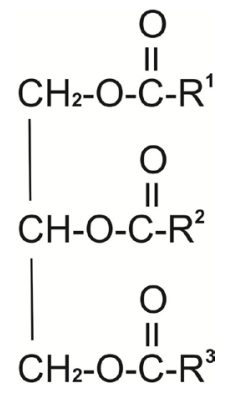

Figure 2. Structure of triglyceride.

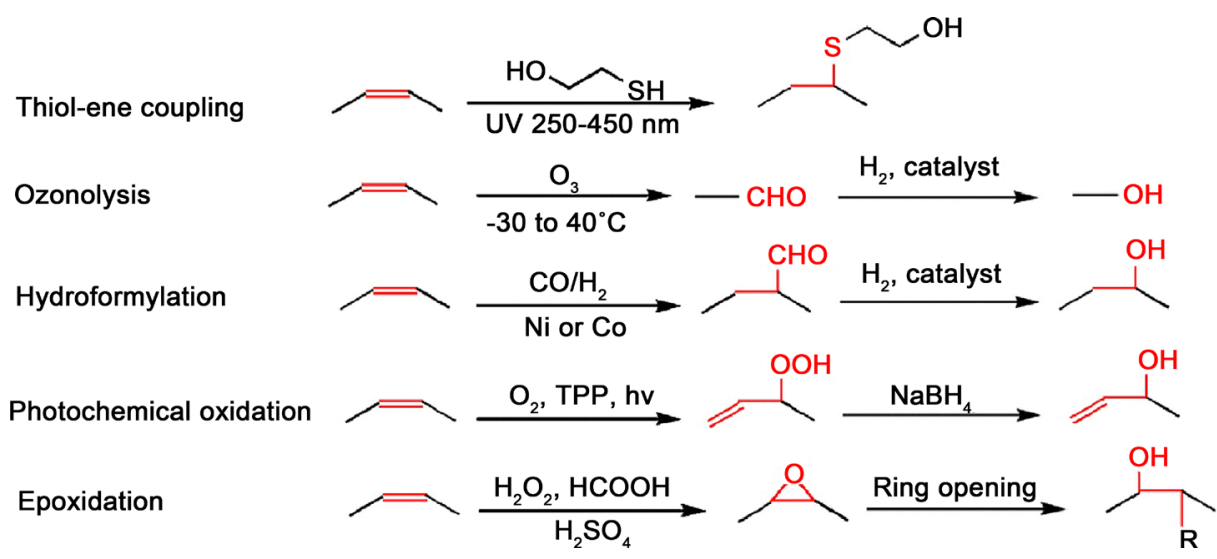

Figure 3. Synthesis method of vegetable-oil-based polyol.

wherein $R^{1}, R^{2}$ and $R^{3}$ are independently saturated or unsaturated aliphatic hydro-carbyl groups containing from about 8 to about 24 carbon atoms.

\section{Synthesis of polyols}

Many routes for the production of vegetable-oil-based polyols are reported including thiolene coupling reaction [94] [95], ozonolysis [96] [97], hydroformylation [98], photochemical oxidation [99], epoxidation [100] [101] [102] [103] followed by ring opening reactions as summarized in Figure 3. Main reaction route for synthesis of polyols is epoxidation and then reaction of the epoxy groups with different ring-opening reagents such as water [104] [105], alcohol [106], glycerol, 1,2-propanodiol [107] and acids [108] [109].

\subsection{Castor 0il}

Castor oil is a major candidate in these replacement efforts due to its inherent advantages over other vegetable oils [110]. Besides its renewability, low cost and easy availability in large quantities, castor oil is not edible, and does not compete with food, and has free secondary hydroxyl groups. Approximately $90 \%$ of fatty acids in castor oil are ricinoleic acid (C18:1), which have a hydroxyl functional group at the $12^{\text {th }}$ carbon. This provides a hydroxyl value of between 160 and 180 $\mathrm{mg} \mathrm{KOH} \mathrm{g}^{-1}$ [111] [112]. However, this low hydroxyl value along with the presence of secondary hydroxyls results in low functionality and low reactivity [113] [114], leading to low crosslinking density, which consequently produces semiflexible and semi-rigid materials among other limitations [115]. 
(a) $\mathrm{n}$

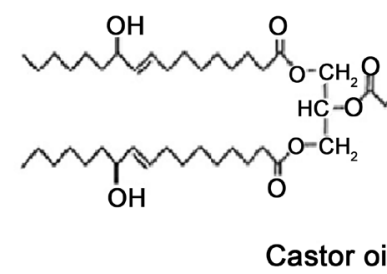

Diacid: Maleic, Fumaric and Oxalic acid

$\mathrm{R}$ : For maleic acid is $\mathrm{CH}=\mathrm{CH}$ in cis form For fumaric acid is $\mathrm{CH}=\mathrm{CH}$ in transform For oxalic acid without $\mathrm{R}$

PU adhesive was prepared using polyols obtained from castor oil modified by a trans-esterification reaction with pentaerythritol [116]. Other work describe the performance of castor oil based novel polyurethane adhesive system for wood to wood and metal to metal bonding by using polyester polyols, castor oil-polyester polyols and epoxy-polyester polyols with different isocyanate adducts having different $\mathrm{NCO} / \mathrm{OH}$ ratio. Castor oil-polyester polyols were synthesized through the transesterification reaction between castor oil and polyester polyols [117]. Castor oil based polyester polyols were synthesized by the condensation polymerization of different dicarboxylic acids such as, maleic acid, fumaric acid, and oxalic acid with castor oil. The prepared polyester polyols were used in the preparation of wood adhesives [118]. Reaction of polyurethane wood adhesives from obtained polyester polyols based on castor oil is shown in Figure 4.

\subsection{Jatropha Oil}

Jatropha oil-based polyol was prepared using two different methods, that is, hydroxylation followed by either alcoholysis or epoxidation of jatropha oil. Epoxidation method of jatropha oil-based polyol had been described in the literature [122]. The synthesized polyol was treated with diisocyanate at $70^{\circ} \mathrm{C}$ to generate the PU adhesive [119] [120] [121] [122] [123]. Reaction scheme is shown in Figure 5.

. 


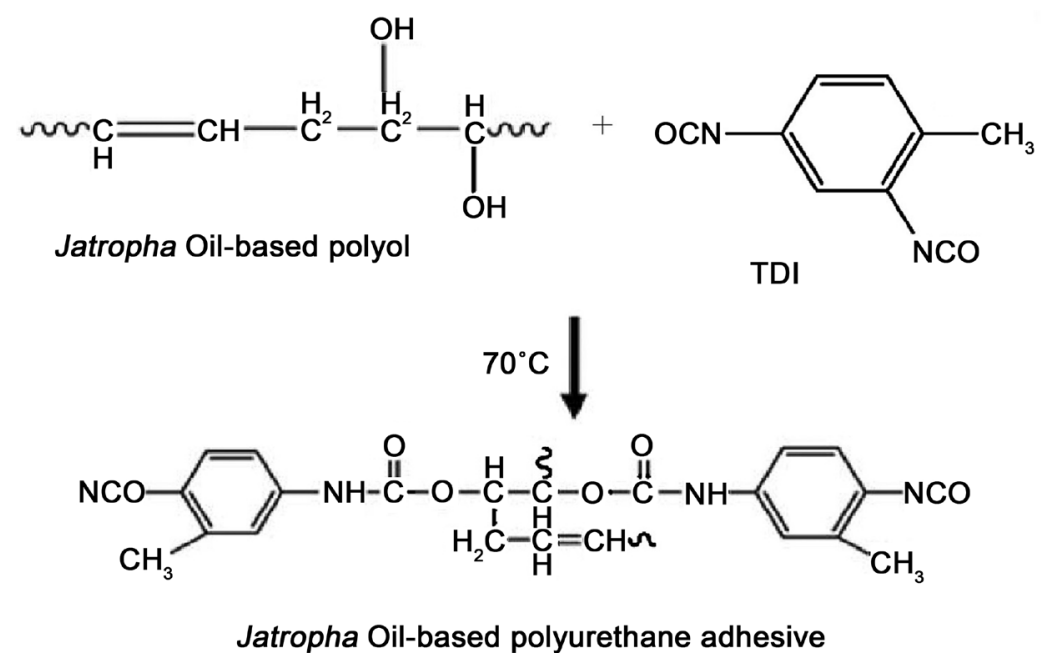

Figure 5. Hydroxylated polyol and prepolymer adhesive reaction with 2,4-toluene diisocyanates.

\subsection{Multi-Hydroxy Soybean Oil (MHSBO)}

The research was conducted to evaluate the possibility of using MHSBO/pMDI resin, obtained from soybean oil, as a wood adhesive. MHSBO was reacted with pMDI resin at different eq. mole ratios to prepare adhesives. These adhesives were used to investigate adhesive properties and bond performance in wood application [124] [125] [126]. Reaction of Synthesis of MHSBO and polyurethanes is shown in Figure 6.

\subsection{Palm 0il}

PU adhesive was prepared from palm oil-based polyester polyol [32] [131] that was synthesized by ring-opening reaction of epoxidized palm olein with phthalic acid. Phthalic acid was used to react with epoxidized palm olein to improve the hydrolytic stability of PU adhesive as cross-linking reaction increases the content of dangling fatty acid chains in the polyol to improve the hydrophobicity of PU adhesives [127]. Besides, the dangling fatty acid chains of the palm oil-based polyester polyols act as plasticizer that gives more flexible adhesive films [128] [129] [130]. Performance of this adhesive system was compared with commercial available wood adhesives. Reaction scheme is shown in Figure 7.

\section{Polylactic Acid Based Polyurethane Adhesive}

Polylactic acid was commercial thermoplastic polyester known for its biodegradability [132]. Preparing polyols from lactic acid (lactate polyols) as precursors for polyurethanes would be beneficial in several ways. Lactate polyols are polyester polyols containing lactic acid units. Introducing lactic acid units into a polyol structure can be done in different ways.

One route was the ring opening addition of lactide to hydroxyl groups. Other routes involve esterification of different polyols with lactic acid, or transesterification with esters of lactic acid (e.g., ethyl lactate, butyl lactate). The advantage 


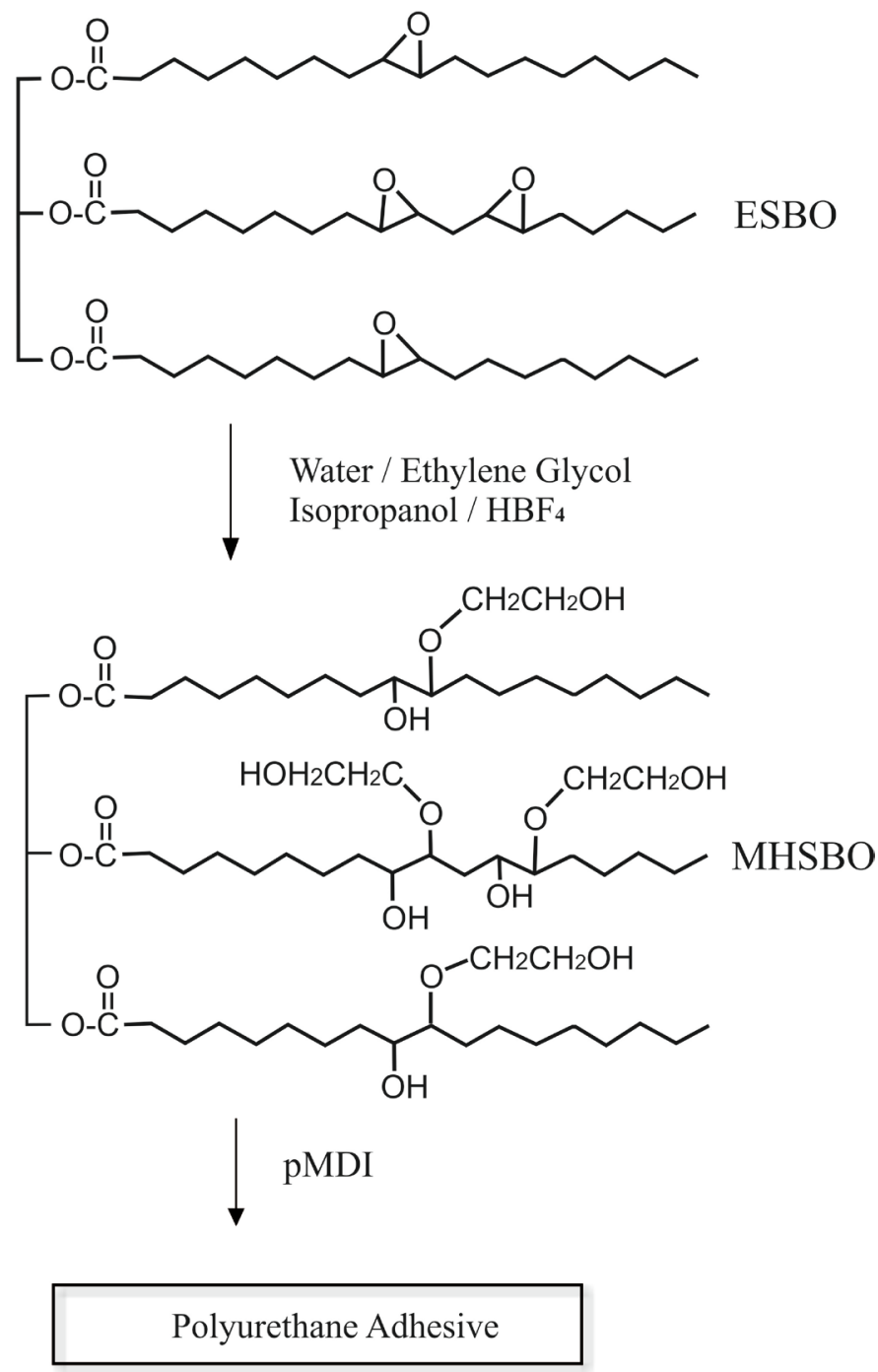

Figure 6. Synthesis of MHSBO and polyurethanes.

of the addition of lactide to polyols was in short reaction times and avoidance of the removal of low molecular weight compounds (water or alcohols). Lactate polyols can be prepared from $100 \%$ bio-renewable feedstock. Present work was to prepare high functionality polyester polyols containing lactic units (lactate polyols) suitable for preparation of rigid cast polyurethanes and foams. This PUs, apart from having high bio-based content, was expected to be biodegradable. The ring opening addition of L-lactide to hydroxyl groups was the reaction used for introducing lactic acid units into polyol structure. In order to obtain high functionality polyols with high bio-based content, different polyglycerols with high content of $\mathrm{OH}$ groups were used as starters. However, high concentration of $\mathrm{OH}$ groups in simple polyglycerol-lactate adducts and strong tendency to crystallization of lactate units result in strong intra-molecular hydrogen bonding, which makes these polyols immiscible with isocyanates. Consequently, this issue was addressed by incorporation of hydrophobic fatty acid segments in the lactate polyol structure, which are known to have good affinity for isocyanates. 
(a)

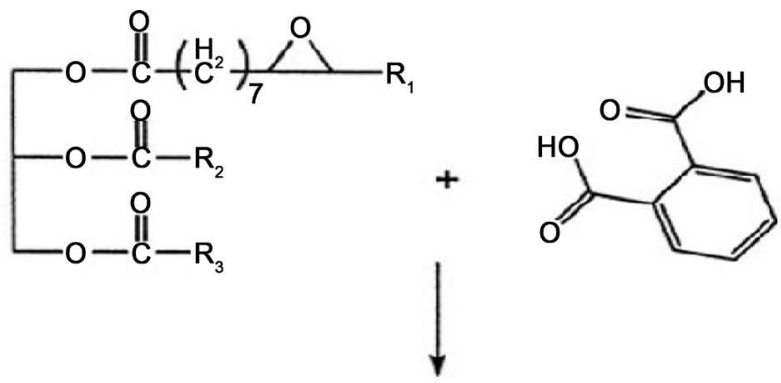

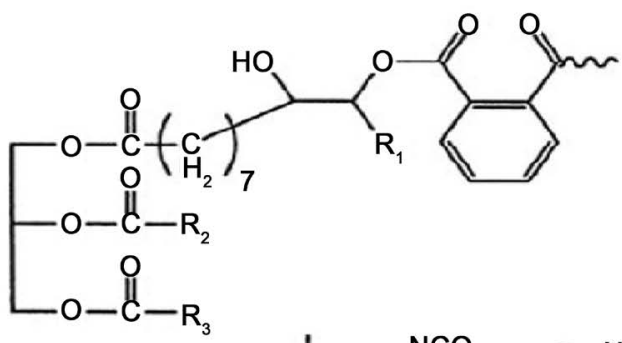

(b)
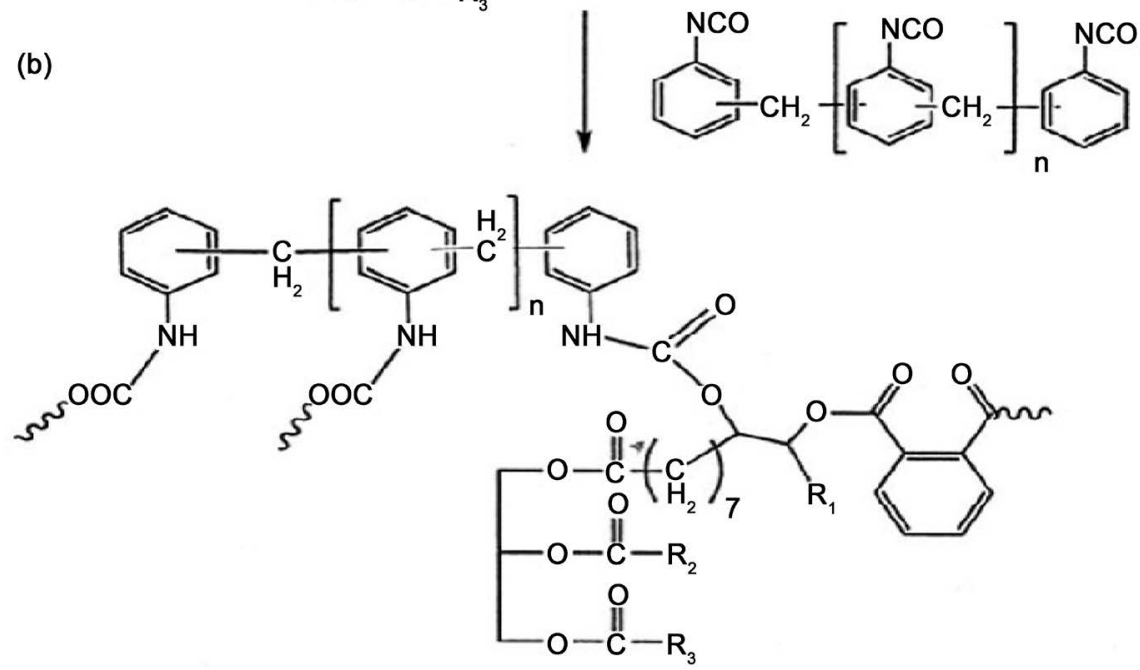

Figure 7. (a) Ring-opening reaction of EPOO by phthalic acid to form polyester polyol. (b) PU formation by reacting polyester polyol with pMDI.

Synthesized lactate polyols were reacted with isocyanate to obtain rigid cast polyurethanes [133] [134].

\section{Potato Starch and Edible or Non-Edible, Plant Derived Oils}

Development of a PU adhesive that is at least partially made from the natural materials potato starch and edible or non-edible, plant derived oils. Because the hydroxyl functionality of the polyol plays an important role in the formation of PU adhesives, polyols having different hydroxyl values were prepared. This was done by means of glycosylation of starch, followed by transesterification with oil to yield polyol [27].

1) Glycosylation of starch

Method of glycosylation was discussed here [135] [136]. The glycol glycoside so prepared, a mixture of a-D glycol glycoside and b-D glycol glycoside was used to synthesize polyols. The reaction is shown in Figure 8. 

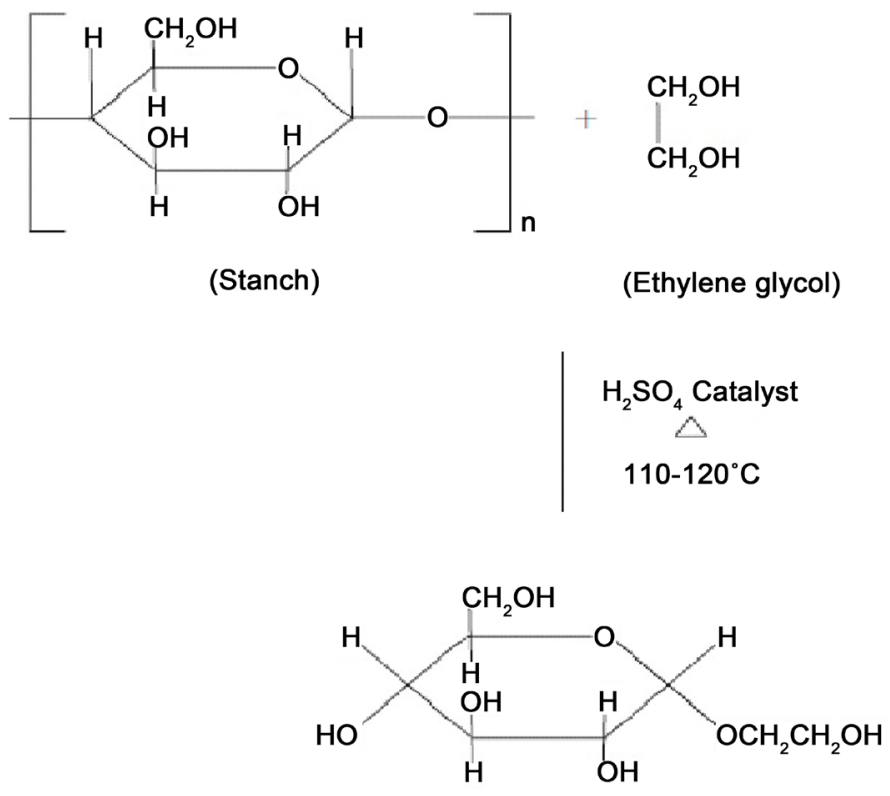

(Glycol alpha -d-glycoside)

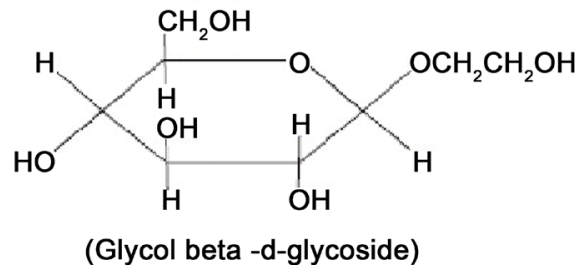

Figure 8. Glycosylation of starch.

2) Alcoholysis of oil with glycol glycoside

Polyols having varying hydroxyl values were synthesized by varying the ratio of glycol glycoside to oil. The reaction is shown in Figure 9.

\section{Lignin Based Polyurethane Adhesive}

Many tons of lignin is generated as by-products of industrial processes such as pulp and paper. Most of the lignin extracted from pulp and paper operations is burned during pulp-spent liquor treatment. This offers energy recovery and regeneration of pulping chemicals with less than $2 \%$ recovered for utilization as a chemical product [137] [138]. However, the amount of lignin produced exceeds the requirements for energy generation. The type of pulping process determines the type of lignin industrially available because it unavoidably modifies the lignin structure from that in the original feedstock.

To increase the potential applications of lignin in polymeric materials, some chemical modifications have been developed [139] [140], but these add stages to the process and/or raise their costs considerably. Therefore, the direct use of industrial lignin is the most favorable option because it is a relatively cheap raw material. Unmodified lignin has poor stability [141] and difficult melt processing [142], which make its direct use uncompetitive. However, many studies have 


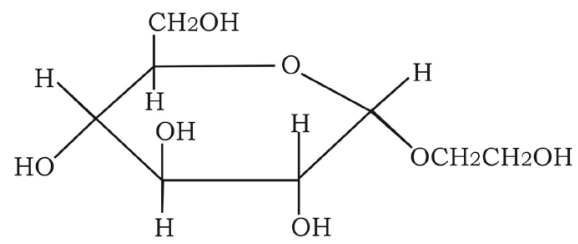

(Glycol glycoside)

$+$

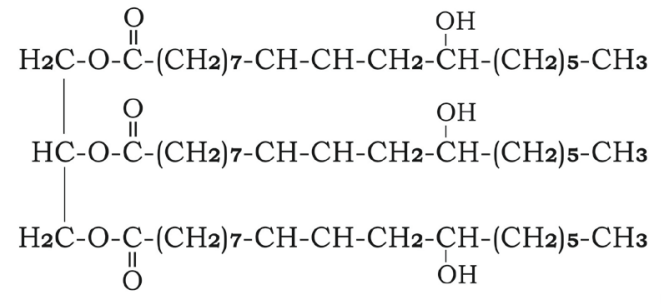

(Oil)

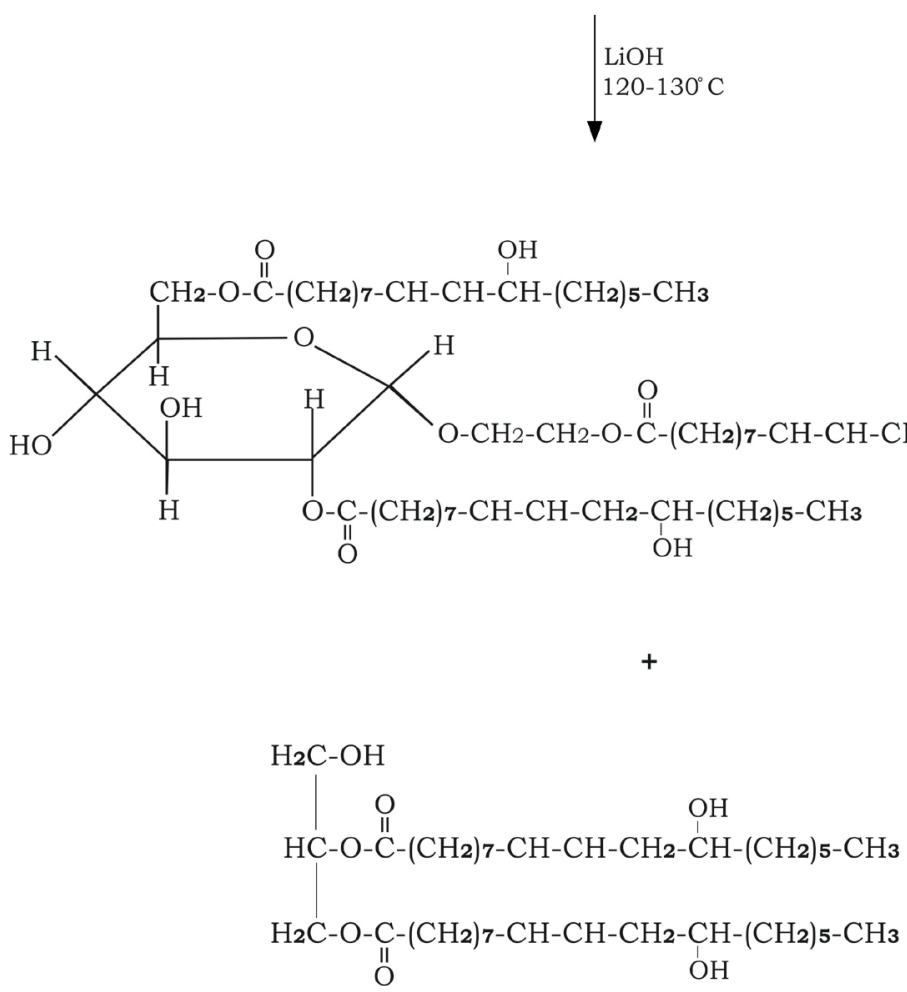

Figure 9. Alcoholysis of oil with glycol glycoside.

focused on the incorporation of lignin in polymer materials by blending it with synthetic or other bio-based polymers [143] [144] [145].

\section{Conclusion and Future Perspectives}

Production of bio renewable PU adhesives from bio resources like plants, trees and algae, is a new area of research due to declining of non-renewable feedstock. Epoxidation is the main route for the synthesis of polyols from vegetable oils (VOs) followed by ring opening reactions. Bio-based di-isocyanate synthesized from fatty acids gives PU with similar physical properties as PU derived from 
petroleum based raw materials. On the other hand faced with declining reserves of fossil fuels, bio-based PU adhesives offer a solution for future challenges because in the future, new products for all industries like coating, paper, packaging, pharmaceutical and textile, for instance, could be created. Some of the chemical companies had already started the bio-based research years ago and other even position bio-based application as future strategy.

\section{References}

[1] Zhang, Q., Zhang, G., Xu, J., Gao, C. and Wu, Y. (2015) Recent Advances on Ligin-Derived Polyurethane Polymers. Reviews on Advanced Materials Science, 40, 146-154.

[2] Ogunniyi, D.S. (2006) Castor Oil: A Vital Industrial Raw Material. Bioresource Technology, 97, 1086-1091. https://doi.org/10.1016/j.biortech.2005.03.028

[3] Madbouly, S.A., Xia, Y. and Kessler, M.R. (2013) Rheological Behavior of Environmentally Friendly Castor Oil-Based Waterborne Polyurethane Dispersions. Macromolecules, 46, 4606-4616. https://doi.org/10.1021/ma400200y

[4] Ashok, C., Vikas, G., Sandip, R., Pramod, M. and Ravindra, K. (2013) Development of Eco-Friendly Polyurethane Coatings Based on Neem Oil Polyetheramide. Industrial Crops and Products, 50, 550-556. https://doi.org/10.1016/j.indcrop.2013.08.018

[5] Beauty, D., Uday, K., Manabendra, M. and Niranjan, K. (2013) Sunflower Oil Based Biodegradable Hyperbranched Polyurethane as a Thin Film Material. Industrial Crops and Products, 44, 396-404. https://doi.org/10.1016/j.indcrop.2012.11.028

[6] Desroches, M., Escouvois, M., Auvergne, R., Caillol, S. and Boutevin, B. (2012) From Vegetable Oils to Polurethane Synthetic Routes to Polyols and Main Industrial Products. Polymer Reviews, 52, 38-79. https://doi.org/10.1080/15583724.2011.640443

[7] Sponton, M., Casis, N., Mazo, P., Raud, B., Simonetta, A., Rios, L. and Estenoz, D. (2013) Biodegradation Study by Pseudomonas sp. of Flexible Polyurethane Foams Derived from Castor Oil. International Biodeterioration \& Biodegradation, 85, 85-94. https://doi.org/10.1016/j.ibiod.2013.05.019

[8] Pfister, D.P., Xia, Y. and Larock, R.C. (2011) Recent Advances in Vegetable Oil-Based Polyurethanes. ChemSusChem, 4, 703-717. https://doi.org/10.1002/cssc.201000378

[9] Tan, S., Abraham, T., Ference, D. and Macosko, C.W. (2011) Rigid Polyurethane Foams from a Soybean Oil-Based Polyol. Polymer, 52, 2840-2846. https://doi.org/10.1016/j.polymer.2011.04.040

[10] Zhang, C., Xia, Y., Chen, R., Huh, S., Johnston, P.A. and Kessler, M.R. (2013) Soy-Castor Oil Based Polyols Prepared Using a Solvent-Free and Catalyst-Free Method and Polyurethanes Therefrom. Green Chemistry, 15, 1477-1484. https://doi.org/10.1039/c3gc40531a

[11] Vick, C.B. and Okkonen, E.A. (1998) Strength and Durability of One-Part Polyurethane Adhesive Bonds to Wood. Forest Products Journal, 48, 71-76.

[12] Desai, S.D., Emanuel, A.L. and Sinha, V.K. (2003) Biomaterial Based Polyurethane Adhesive for Bonding Rubber and Wood Joints. Journal of Polymer Research, 10, 275-281. https://doi.org/10.1023/B:JPOL.0000004630.77120.bb

[13] Pizzi, A. (1983) Wood Adhesives Chemistry, Technology, Vol. 12. Marcel Dekker, New York.

[14] Skeist, I. (1962) Hand Book of Adhesives, Vol. 669. Van Nostrand Reinhold, New York. 
[15] Packham, D.E. (1992) Hand Book of Adhesives, Vol. 407. Longman, London.

[16] Pizzi, A. (2000) Tannery Row-The Story of Some Natural and Synthetic Wood Adhesives. Wood Science and Technology, 34, 277-316. https://doi.org/10.1007/s002260000052

[17] Myers, G.E. (1988) New Technologies and Materials for Bonding Wood Products. Adhesives Age, 31, 31-36.

[18] Ebewele, R.O., River, B.H. and Myres, G.E. (1994) Failure Mechanisms in Wood Joints Bonded with Urea-Formaldehyde Adhesives. European Journal of Wood and Wood Products, 52, 179-184. https://doi.org/10.1007/BF02615219

[19] Freeman, G.G. and Krebich, S. (1968) Estimating Durability of Wood Adhesives in Vitro. Forest Products Journal, 18, 39-43.

[20] Tranghton, G.E. and Chow, S. (1968) Accelerated Aging of Glue-Wood Bonds. Journal of the Institute of Wood Science, 21, 29-34.

[21] Dinwoodie, J.M. (1978) The Properties and Performance of Particleboard Adhesives. Journal of the Institute of Wood Science, 8, 59-67.

[22] Wilson, J.B. (1981) Isocyanate Adhesive as Binders for Composition Board. Adhesive Age, 41

[23] John, N. and Joseph, R. (1998) Rubber Solution Adhesives for Wood-To Wood Bonding. Journal of Applied Polymer Science, 68, 1185-1189.

https://doi.org/10.1002/(SICI)1097-4628(19980516)68:7<1185::AID-APP15>3.0.CO $\underline{; 2-\mathrm{X}}$

[24] Osrekar, U. and Malavasic, T. (1992) International Journal of Adhesion and Adhesives, 112,38 .

[25] Oertel, G. (1985) Polyurethane Handbook. Hanser Publisher, Munich.

[26] Desai, S.D., Patel, J.V. and Sinha, V.K. (2003) Polyurethane Adhesive System from Biomaterial-Based Polyol for Bonding Wood. International Journal of Adhesion and Adhesives, 23, 393-399. https://doi.org/10.1016/S0143-7496(03)00070-8

[27] Gadhave, R.V., Mahanwar, P.A. and Gadekar, P.T. (2017) Starch-Based Adhesives for Wood/Wood Composite Bonding: Review. Open Journal of Polymer Chemistry, 7, 19-32. https://doi.org/10.4236/ojpchem.2017.72002

[28] Sanchez-Adsuar, M.S. and Martin-Martinez, J.M. (2000) Structure, Composition, and Adhesion Properties of Thermoplastic Polyurethane Adhesives. Journal of Adhesion Science and Technology, 14, 1035-1055. https://doi.org/10.1163/156856100743068

[29] Lligadas, G., Ronda, J.C., Galià, M. and Cádiz, V. (2007) Poly(Ether Urethane) Networks from Renewable Resources as Candidate Biomaterials: Synthesis and Characterization. Biomacromolecules, 8, 686-692. https://doi.org/10.1021/bm060977h

[30] Somani, K.P., Kansara, S.S., Patel, N.K. and Rakshit, A.K. (2003) Castor Oil Based Polyurethane Adhesives for Wood-to-Wood Bonding. International Journal of Adhesion and Adhesives, 23, 269-275. https://doi.org/10.1016/S0143-7496(03)00044-7

[31] Silva, B.B.R., Santana, R.M.C. and Forte, M.M.C. (2010) A Solventless Castor Oil-Based PU Adhesive for Wood and Foam Substrates. International Journal of Adhesion and Adhesives, 30, 559-565. https://doi.org/10.1016/j.ijadhadh.2010.07.001

[32] Badri, K.H., Ujar, A.H. and Othman, Z. (2006) Shear Strength of Wood to Wood Adhesive Based on Palm Kernel Oil. Journal of Applied Polymer Science, 100, 1759-1764. https://doi.org/10.1002/app.23015 
[33] Kong, X. and Liu, G. (2011) Characterization of Canola Oil Based Polyurethane Wood Adhesives. International Journal of Adhesion and Adhesives, 31, 559-564. https://doi.org/10.1016/j.ijadhadh.2011.05.004

[34] Choi, S.W., Seo, D.W., Lim, Y.D., Jeong, Y.G. Islam Mollah, M.S., Park, H., Hong, T.W. and Kim, W.G. (2011) Synthesis and Properties of Multihydroxy Soybean Oil from Soybean Oil and Polymeric Methylene-Diphenyl-4,4'-diisocyanate/multihydroxy Soybean Oil Polyurethane Adhesive to Wood. Journal of Applied Polymer Science, 121, 764-769. https://doi.org/10.1002/app.33405

[35] Brister, E.H., Johnston, T., King, C.L. and Thames, S.F. (2000) New Monomers from Vegetable Oils. In: Havelka, K.O. and Mc Cormick, C.L., Eds., Specialty Monomers and Polymers, ACS Symposium Series, Vol. 755, American Chemical Society, Washington DC, 159-169.

[36] Azam Ali, M., Ooi, T.L., Salmiah, A., Ishiaku, U.S. and Mohd. Ishak, Z.A. (2001) New Polyester Acrylate Resins from Palm Oil for Wood Coating Application. Journal of Applied Polymer Science, 79, 2156-2163. https://doi.org/10.1002/1097-4628(20010321)79:12<2156::AID-APP1023>3.0.CO;2$\underline{\mathrm{K}}$

[37] Homan, J.G., Yu, X.H., Connor, T.J. and Cooper, S.L. (1991) Castor Oil Based UV-Curable Polyurethane-Acrylate Interpenetrating Networks. Journal of Applied Polymer Science, 43, 2249-2257. https://doi.org/10.1002/app.1991.070431214

[38] Khot, S.N. and Wool, R.P. (2000) Composite from Natural Fibers and Soy Oil Resins. Applied Composite Materials, 7, 421-431.

[39] Bunker, S.P. and Wool, R.P. (1991) In: Gabelein, C.G., Ed., Biotechnology and Polymers, Plenum Press, New York.

[40] Grinberg, S., Kolot, V. and Mills, D. (1996) Proceedings of the 61 st Meeting of the Israel Chemical Society, Jerusalem, 13-14 February 1996.

[41] Grinberg, S. and Kolot, V. (2000) Proceedings of the 91 st American Oil Chemists Society Annual Meeting and Exposition, San Diego, 25-28 April 2000, S119.

[42] Mahendran, A.R., Wuzella, G., Kandelbauer, A. and Aust, N. (2012) Thermal Cure Kinetics of Epoxidized Linseed Oil with Anhydride Hardener. Journal of Thermal Analysis and Calorimetry, 107, 989-998. https://doi.org/10.1007/s10973-011-1585-7

[43] Khot, S.N., Lascala, J.J., Can, E., Morye, S.S., Williams, G.I., Palmese, G.R., Kusefoglu, S.H. and Wool, R.P. (2001) Development and Application of Triglyceride-Based Polymers and Composites. Journal of Applied Polymer Science, 82, 703-723. https://doi.org/10.1002/app.1897

[44] Pelletier, H. and Gandini, A. (2006) Preparation of Acrylated and Urethanated Triacylglycerols. European Journal of Lipid Science and Technology, 108, 411-420. https://doi.org/10.1002/ejlt.200501168

[45] Derksen, J.T.P., Cuperus, F.P. and Kolster, P. (1996) Renewable Resources in Coatings Technology: A Review. Progress in Organic Coatings, 27, 45-53. https://doi.org/10.1016/0300-9440(95)00518-8

[46] Sharmin, E., Ashraf, S.M. and Ahmad, S. (2007) Epoxidation, Hydroxylation, Acrylation and Urethanation of Linum usitatissimum Seed Oil and Its Derivatives. European Journal of Lipid Science and Technology, 109, 134-146. https://doi.org/10.1002/ejlt.200600227

[47] Mosiewicki, M.A. and Aranguren, M.I. (2013) A Short Review on Novel Biocomposites Based on Plant Oil Precursors. European Polymer Journal, 49, 1243-1256. https://doi.org/10.1016/j.eurpolymj.2013.02.034

[48] Miao, S., Wang, P., Su, Z. and Zhang, S. (2014) Vegetable-Oil-Based Polymers as 
Future Polymeric Biomaterials. Acta Biomaterialia, 10, 1692-1704. https://doi.org/10.1016/j.actbio.2013.08.040

[49] Perkin, G., Vardar-Sukan, F. and Kosaric, N. (2005) Production of Sophorolipids from Candida bombicola ATCC 22214 Using Turkish Corn Oil and Honey. Engineering in Life Sciences, 5, 357-362. https://doi.org/10.1002/elsc.200520086

[50] La Scala, J. and Wool, R.P. (2005) Property Analysis of Triglyceride-Based Thermosets. Polymer, 46, 61-69. https://doi.org/10.1016/j.polymer.2004.11.002

[51] Lu, Y. and Larock, R.C. (2008) Soybean-Oil-Based Waterborne Polyurethane Dispersions: Effect of Polyol Functionality and Hard Segment Content on Properties. Biomacromolecules, 9, 3332-3340. https://doi.org/10.1021/bm801030g

[52] Athawale, V.D., Pillay, P.S. and Kolekar, S.L. (2001) Polyurethane Based on Hydrogenated Castor Oil. European Coatings Journal, 1-2, 18-24.

[53] Lligadas, G., Ronda, J.C., Galia, M. and Cadiz, V. (2013) Renewable Polymeric Materials from Vegetable Oils: A Perspective. Materials Today, 16, 337-343. https://doi.org/10.1016/j.mattod.2013.08.016

[54] Kong, X., Liu, G., Qi, H. and Curtis, J.M. (2013) Preparation and Characterization of High-Solid Polyurethane Coating Systems Based on Vegetable Oil Derived Polyols. Progress in Organic Coatings, 76, 1151-1160.

https://doi.org/10.1016/j.porgcoat.2013.03.019

[55] Garrison, T.F., Larock, R.C. and Kessler, M.R. (2014) Effects of Unsaturation and Different Ring Opening Methods on the Properties of Vegetable Oil-Based Polyurethane Coatings. Polymer, 55, 1004-1011.

https://doi.org/10.1016/j.polymer.2014.01.014

[56] F., Akram, D. and Ahmad, S. (2013) Plant oil Polyol Nanocomposite Terial Polyurethane Coating. Progress in Organic Coatings, 76, 541-547.

https://doi.org/10.1016/j.porgcoat.2012.10.027

[57] Sharmin, E., Akram, D., Zafar, F., Ashraf, S.M. and Ahmad, S. (2012) Plant Oil Polyol Based Poly(Ester Urethane) Metallohybrid Coatings. Progress in Organic Coatings, 73, 118-122. https://doi.org/10.1016/j.porgcoat.2011.09.008

[58] Benhamou, K., Kaddami, H., Magnin, A., Dufresne, A. and Ahmad, A. (2015) Bio-Based Polyurethane Reinforced with Cellulose Nanofibers: A Comprehensive Investigation on the Effect of Interface. Carbohydrate Polymers, 122, 202-211. https://doi.org/10.1016/j.carbpol.2014.12.081

[59] Deka, H. and Karak, N. (2009) Bio-Based Hyperbranched Polyurethanes for Surface Coating Applications. Progress in Organic Coatings, 66, 192-198.

https://doi.org/10.1016/j.porgcoat.2009.07.005

[60] Rajput, S.D., Hundiwale, D.G., Mahulikar, P.P. and Gite, V.V. (2014) Fatty Acids Based Transparent Polyurethane Films and Coatings. Progress in Organic Coatings, 77, 1360-1368. https://doi.org/10.1016/j.porgcoat.2014.04.030

[61] Rajput, S.D., Mahulikar, P.P. and Gite, V.V. (2014) Biobased Dimer Fatty Acid Containing Two Pack Polyurethane for Wood Finished Coatings. Progress in Organic Coatings, 77, 38-46. https://doi.org/10.1016/j.porgcoat.2013.07.020

[62] Mahendrana, A.R., Wuzellaa, G., Austb, N., Kandelbauerc, A. and Mullera, U. (2012) Thermal Cure Kinetics of Epoxidized Linseed Oil with Anhydride Hardener. Progress in Organic Coatings, 74, 697-704.

[63] Saalah, S., Abdullah, L.C., Aung, M.M., Sallehd, M.Z., Biaka, D.R.A., Basrie, M. and Jusoh, E.R. (2015) Waterborne Polyurethane Dispersions Synthesized from Jatropha Oil. Industrial Crops and Products, 64, 194-200. 
https://doi.org/10.1016/j.indcrop.2014.10.046

[64] Lee, T.J., Kwon, S.H. and Kim, B.K. (2014) Biodegradable Sol-Gel Coatings of Waterborne Polyurethane /Gelatin Chemical Hybrids. Progress in Organic Coatings, 77, 1111-1116. https://doi.org/10.1016/j.porgcoat.2014.03.011

[65] Chaudharia, A., Gitea, V., Rajputa, S., Mahulikara, P. and Kulkarni, R. (2013) Development of Eco-Friendly Polyurethane Coatings Based on Neem Oil Polyetheramide. Industrial Crops and Products, 50, 550-556.

https://doi.org/10.1016/j.indcrop.2013.08.018

[66] Chaudhari, A.B., Anand, A., Rajput, S.D., Kulkarni, R.D. and Gite, V.V. (2013) Synthesis, Characterization and Application of Azadirachta indica Juss (Neem Oil) Fatty Amides (AIJFA) Based Polyurethanes Coatings: A Renewable Novel Approach. Progress in Organic Coatings, 76, 1779-1785.

https://doi.org/10.1016/j.porgcoat.2013.05.016

[67] Qu, J. and Chen, H. (2004) Studies on Syntheses and Properties of Waterborne Polyurethane Resin from Castor Oil. Chemistry and Industry of Forest Products, 24, 78-82.

[68] Fu, C., Yang, Z., Zheng, Z. and Shen, L. (2014) Properties of Alkoxysilane Castor Oil Synthesized via Thiolene and Its Polyurethane/Siloxane Hybrid Coating Films. Progress in Organic Coatings, 77, 1241-1248. https://doi.org/10.1016/j.porgcoat.2014.03.020

[69] Thakur, S. and Karak, N. (2013) Castor Oil-Based Hyperbranched Polyurethanes as Advanced Surface Coating Materials. Progress in Organic Coatings, 76, 157-164. https://doi.org/10.1016/j.porgcoat.2012.09.001

[70] Li, K., Shen, Y., Fei, G., Wang, H. and Li, J. (2015) Preparation and Properties of Castor Oil/Pentaerythritol Triacrylate-Based UV Curable Waterborne Polyurethane Acrylate. Progress in Organic Coatings, 78, 146-154. https://doi.org/10.1016/j.porgcoat.2014.09.012

[71] Patel, D.P., Nimavat, K.S. and Vyas, K.B. (2011) Surface Coating Studies of Polyurethane Derived from [(Alkyd)-(Epoxy Resin Treated Castor Oil)] Isocyanate Terminated Castor Oil Mixture. Advances in Applied Science Research, 2, 558-566.

[72] Chang, C.-W. and Lu, K.-T. (2012) Natural Castor Oil Based 2-Package Waterborne Polyurethane Wood Coatings. Progress in Organic Coatings, 75, 435-443. https://doi.org/10.1016/j.porgcoat.2012.06.013

[73] Caki, S.M., Risti, I.S., Cincovi, M.M., Stojiljkovi, D.T., Janosd, C.J., Miroslave, C.J. and Stamenkovi, J.V. (2015) Preparation and Properties of Aqueous Castor Oil-Based Polyurethane-Silica Nanocomposite Dispersions through a Sol-Gel Process. Progress in Organic Coatings, 78, 357-368.

[74] Ismail, E.A., Motawie, A.M. and Sadek, E.M. (2011) Synthesis and Characterization of Polyurethane Coatings Based on Soybean Oil-Polyester Polyols. Egyptian Journal of Petroleum, 20, 1-8. https://doi.org/10.1016/j.ejpe.2011.06.009

[75] Bakhshi, H., Yeganeh, H., Ataei, S.M., Shokrgozar, M.A., Yari, A. and Eslami, S.N.S. (2013) Synthesis and Characterization of Antibacterial Polyurethane Coatings from Quaternary Ammonium Salts Fictionalized Soybean Oil Based Polyols. Materials Science and Engineering: C, 33, 153-164.

https://doi.org/10.1016/j.msec.2012.08.023

[76] Velayutham, T.S., Abd Majid, W.H., Ahmad, A.B., Kang, G.Y. and Gan, S.N. (2009) Synthesis and Characterization of Polyurethane Coatings Derived from Polyols Synthesized with Glycerol, Phthalic Anhydride and Oleic Acid. Progress in Organic Coatings, 66, 367-371. https://doi.org/10.1016/j.porgcoat.2009.08.013 
[77] Philipp, C. and Eschig, S. (2012) Waterborne Polyurethane Wood Coatings Based on Rapeseed Fatty Acid Methyl Esters. Progress in Organic Coatings, 74, 705-711. https://doi.org/10.1016/j.porgcoat.2011.09.028

[78] Kong, X., Liu, G. and Curtis, J.M. (2012) Novel Polyurethane Produced from Canola Oil Based Poly(Ether Ester) Polyols: Synthesis, Characterization and Properties. European Polymer Journal, 48, 2097-2106. https://doi.org/10.1016/j.eurpolymj.2012.08.012

[79] Sharma, H.O., Alam, M., Riaz, U., Ahmad, S. and Ashraf, S.M. (2007) Miscibility studies of Polyesteramides of Linseed Oil and Dehydrated Castor Oil with Poly(Vinyl Alcohol). International Journal of Polymeric Materials and Polymeric Biomaterials, 56, 437-451. https://doi.org/10.1080/00914030600904611

[80] Chang, C.W. and Lu, K.T. (2013) Linseed-Oil-Based Waterborne UV/Air Dual-Cured Wood Coatings. Progress in Organic Coatings, 76, 1024-1031. https://doi.org/10.1016/j.porgcoat.2013.02.020

[81] Sharmin, E., Ashraf, S.M. and Ahmad, S. (2007) Synthesis, Characterization, Antibacterial and Corrosion Protective Properties of Epoxies, Epoxy-Polyols and Epoxy-Polyurethane Coatings from Linseed and Pongamia glabra Seed Oils. International Journal of Biological Macromolecules, 40, 407-422. https://doi.org/10.1016/j.ijbiomac.2006.10.002

[82] Dutta, S. and Karak, N. (2005) Synthesis, Characterization of Poly (Urethane Amide) Resins from Nahar Seed Oil for Surface Coating Applications. Progress in Organic Coatings, 53, 147-152. https://doi.org/10.1016/j.porgcoat.2005.02.003

[83] Alam, M. and Alandis, N.M. (2014) Corn Oil Based Poly(Ether Amide Urethane) Coating Material-Synthesis, Characterization and Coating Properties. Industrial Crops and Products, 57, 17-28. https://doi.org/10.1016/j.indcrop.2014.03.023

[84] Dutta, N., Karak, N. and Dolui, S.K. (2004) Synthesis and Characterization of Polyester Resins Based on Nahar Seed Oil. Progress in Organic Coatings, 49, 146-152. https://doi.org/10.1016/j.porgcoat.2003.09.005

[85] Liu, G., Wu, G., Jin, C. and Kong, Z. (2015) Preparation and Antimicrobial Activity of Terpene-Based Polyurethane Coatings with Carbamate Group-Containing Quaternary Ammonium Salts. Progress in Organic Coatings, 80, 150-155. https://doi.org/10.1016/j.porgcoat.2014.12.005

[86] Dutta, S. and Karak, N. (2006) Effect of the NCO/OH Ratio on the Properties of Mesua ferrea L. Seed Oil-Modified Polyurethane Resins. Polymer International, 55, 49-56. https://doi.org/10.1002/pi.1914

[87] Kathalewar, M., Sabnis, A. and D’Melo, D. (2014) Polyurethane Coatings Prepared from CNSL Based Polyols: Synthesis, Characterization and Properties. Progress in Organic Coatings, 77, 616-626. https://doi.org/10.1016/j.porgcoat.2013.11.028

[88] Patel, C.J. and Mannari, V. (2014) Air-Drying Bio-Based Polyurethane Dispersion from Cardanol: Synthesis and Characterization of Coatings. Progress in Organic Coatings, 77, 997-1006. https://doi.org/10.1016/j.porgcoat.2014.02.006

[89] Araújo, R.C.S. and Pasa, V.M.D. (2004) New Eucalyptus Tar-Derived Polyurethane Coatings. Progress in Organic Coatings, 51, 6-14. https://doi.org/10.1016/j.porgcoat.2014.02.006

[90] Araujoa, R.C.S., Pasaa, V.M.D., Marriottb, P.J., Cardeal, Z.L. and Anal, J. (2010) Analysis of Volatile Organic Compounds in Polyurethane Coatings Based on Eucalyptus sp. Bio-Oil Pitch Using Comprehensive Two Dimensional Gas Chromatography (GC*GC). Journal of Analytical and Applied Pyrolysis, 88, 91-97. https://doi.org/10.1016/j.jaap.2010.02.012 
[91] Thébault, M., Pizzi, A., Essawy, H.A., Barhoum, A. and Van Assche, G. (2015) Isocyanate Free Condensed Tannin-Based Polyurethanes. European Polymer Journal, 67, 513-526. https://doi.org/10.1016/j.eurpolymj.2014.10.022

[92] Tong, X., Luo, X. and Li, Y. (2015) Development of Blend Films from Soy Meal Protein and Crude Glycerol-Based Waterborne Polyurethane. Industrial Crops and Products, 67, 11-17. https://doi.org/10.1016/j.indcrop.2014.12.063

[93] Kathalewar, M., Sabnis, A. and D’Mello, D. (2014) Isocyanate Free Polyurethanes from New CNSL Based Bis-Cyclic Carbonate and Its Application in Coatings. European Polymer Journal, 57, 99-108. https://doi.org/10.1016/j.eurpolymj.2014.05.008

[94] González-Paz, R.J., Lluch, C., Lligadas, G., Ronda, J.C., Galià, M. and Cádiz, V. (2011) A Green Approach Toward Oleic- and Undecylenic Acid Derived Polyurethanes. Journal of Polymer Science Part A, 49, 2407-2416. https://doi.org/10.1002/pola.24671

[95] Desroches, M., Caillol, S., Lapinte, V., Auvergne, R. and Boutevin, B. (2011) Synthesis of Biobased Polyyols by Thiolene Coupling from Vegetable Oils. Macromolecules, 44, 2489-2500. https://doi.org/10.1021/ma102884w

[96] Petrovic, Z.S., Zhang, W. and Javni, I. (2005) Structure and Properties of Polyurethanes Prepared from Triglyceride Polyols by Ozonolysis. Biomacromolecules, 6, 713-719. https://doi.org/10.1021/bm049451s

[97] Narine, S.S., Kong, X., Bouzidi, L. and Sporns, P. (2007) Physical Properties of Polyurethanes Produced from Polyols from Seed Oils: I. Elastomers. Journal of the American Oil Chemists' Society, 84, 55-63. https://doi.org/10.1007/s11746-006-1006-4

[98] Petrovic, Z.S., Guo, A., Javni, I., Cvetkovic, I. and Hong, D.P. (2007) Polyurethane Networks from Polyols Obtained by Hydroformylation of Soybean Oil. Polymer International, 57, 275-281. https://doi.org/10.1002/pi.2340

[99] Ronda, J.C., Lligadas, G., Galià, M. and Cádiz, V. (2011) Vegetable Oils as Platform Chemicals for Polymer Synthesis. European Journal of Lipid Science and Technology, 113, 46-58. https://doi.org/10.1002/ejlt.201000103

[100] Goud, V.V., Patwardhan, A.V., Dinda, S. and Pradhan, N.C. (2007) Kinetics of in Situ Epoxidation of Jatropha Oil by Peroxyacetic and Peroxyformic Acid Catalysed by Acidic Ion Exchange Resin. Chemical Engineering Science, 62, 4065-4076. https://doi.org/10.1016/j.ces.2007.04.038

[101] Gerbase, A.E., Gregorio, J.R., Martinelli, M., Brasil, M.C. and Mendes, A.N.F. (2002) Epoxidation of Soybean by the Methyltritioxorhenium- $\mathrm{CH}_{2} \mathrm{Cl}_{2} / \mathrm{H}_{2} \mathrm{O}_{2}$ Catalytic Biphaseic System. Journal of the American Oil Chemists' Society, 79, 179-181. https://doi.org/10.1007/s11746-002-0455-0

[102] Lie Ken Jie, M.S.F. and Yan-Kit, C. (1988) The Use of a Microwave Oven in the Chemical Transformation of Long Chain Fatty Acid Esters. Lipids, 23, 367-369. https://doi.org/10.1007/BF02537351

[103] Campanella, A., Baltanas, M., Capel-Sanchez, M., Campos-Martin, J. and Fierro, J. (2004) Soybean Oil Epoxidation with Hydrogen Peroxide Using an Amorphous $\mathrm{Ti} / \mathrm{SiO}_{2}$ Catalyst. Green Chemistry, 6, 330-334. https://doi.org/10.1039/B404975F

[104] Harry-O'Kuru, R. and Carriere, C. (2002) Synthesis, Rheological Characterization, and Constitutive Modeling of Polyhydroxy Tiglycerides Derived from Milkweed Oil. Journal of Agricultural and Food Chemistry, 50, 3214-3221. https://doi.org/10.1021/jf011464z

[105] Adhvaryu, A., Liu, Z. and Erhan, S.Z. (2005) Synthesis of Novel Alkoxylated Tricyl- 
glycerols and Their Lubricant Base Oil Properties. Industrial Crops and Products, 21, 113-119. https://doi.org/10.1016/j.indcrop.2004.02.001

[106] Ionescu, M., Petrović, Z.S. and Wan, X. (2007) Ethoxylated Soybean Polyols for Polyurethanes. Journal of Polymers and the Environment, 15, 237-243. https://doi.org/10.1007/s10924-007-0065-4

[107] Wang, C.S., Yang, L.T., Ni, B.L. and Shi, G. (2009) Polyurethane Networks from Different Soy-Based Polyols by the Ring-Opening of Epoxidized Soybean Oil with Methanol, Glycol, and 1,2-Propanediol. Journal of Applied Polymer Science, 114, 125-131. https://doi.org/10.1002/app.30493

[108] Guo, Y., Hardesty, J.H., Mannari, V.M. and Massingill, J.L. (2007) Hydrolysis of Epoxidized Soyban Oil in the Presence of Phosphoric Acid. Journal of the American Oil Chemists' Society, 84, 929-935. https://doi.org/10.1007/s11746-007-1126-5

[109] Noreen, A., Zia, K.M., Zuber, M., Tabasum, S. and Zahoor, A.F. (2016) Bio-Based Polyurethane: An Efficient and Environment Friendly Coating Systems: A Review. Progress in Organic Coatings, 91, 25-32. https://doi.org/10.1016/j.porgcoat.2015.11.018

[110] Zhang, L., Zhang, M., Hu, L. and Zhou, Y. (2014) Synthesis of Rigid Polyurethane Foams with Castor Oil-Based Flame Retardant Polyols. Industrial Crops and Products, 52, 380-388. https://doi.org/10.1016/j.indcrop.2013.10.043

[111] Karak, N., Rana, S. and Cho, J.W. (2009) Synthesis and Characterization of Castor-Oil-Modified Hyperbranched Polyurethanes. Journal of Applied Polymer Science, 112, 736-743. https://doi.org/10.1002/app.29468

[112] Zhang, M., Pan, H., Zhang, L., Hu, L. and Zhou, Y. (2014) Study of the Mechanical, Thermal Properties and Flame Retardancy of Rigid Polyurethane Foams Prepared from Modified Castor-Oil-Based Polyols. Industrial Crops and Products, 59, 135-143. https://doi.org/10.1016/j.indcrop.2014.05.016

[113] Gallezot, P. (2012) Conversion of Biomass to Selected Chemical Products. Chemical Society Reviews, 41, 1538-1558. https://doi.org/10.1039/C1CS15147A

[114] Sharma, C., Kumar, S., Unni, A.R., Aswal, V.K., Rath, S.K. and Harikrishnan, G. (2014) Foam Stability and Polymer Phase Morphology of Flexible Polyurethane Foams Synthesized from Castor Oil. Journal of Applied Polymer Science, 131, 8420-8427. https://doi.org/10.1002/app.40668

[115] Mutlu, H. and Meier, M.A.R. (2010) Castor Oil as a Renewable Resource for the Chemical Industry. European Journal of Lipid Science and Technology, 112, 10-30. https://doi.org/10.1002/ejlt.200900138

[116] Valero, M.F. and Gonzalez, A. (2012) Polyurethane Adhesive System from Castor Oil Modified by a Transesterification Reaction. Journal of Elastomers \& Plastics, 44, 433-442. https://doi.org/10.1177/0095244312437155

[117] Patel, M.R., Shukla, J.M., Patel, N.K. and Patel, K.H. (2009) Biomaterial Based Novel Polyurethane Adhesives for Wood to Wood and Metal to Metal Bonding. Materials Research (Sao Carlos, Braz.), 12, 385-393.

[118] Moghadam, P.N., Yarmohamadi, M., Hasanzadeh, R. and Nuri, S. (2016) Preparation of Polyurethane Wood Adhesives by Polyols for Mulated with Polyester Polyols Based on Castor Oil. International Journal of Adhesion and Adhesives, 68, 273-282. https://doi.org/10.1016/j.ijadhadh.2016.04.004

[119] Aung, M.M., Yaakob, Z., Kamarudin, S. and Abdullah, L.C. (2014) Synthesis and Characterization of Jatropha (Jatropha curcas L.) Oil-Based Polyurethane Wood Adhesive. Industrial Crops and Products, 60, 177-185. https://doi.org/10.1016/j.indcrop.2014.05.038 
[120] Abdul, K.H.P.S., Sro Aprilia, N.A., Bhat, A.H., Jawaid, M., Paridah, M.T. and Rudi, D.A. (2013) Jatropha Biomass as Renewable Materials for Biocomposites and Its Applications. Renewable and Sustainable Energy Reviews, 22, 667-685. https://doi.org/10.1016/j.rser.2012.12.036

[121] Akbar, E., Yaakob, Z., Kamaruddin, S.K., Isamil, M. and Jumat, S. (2009) Characteristic and Composition of Jatropha curcas Oil Seed from Malaysia and Its Potential as Biodiesel Feedstock. European Journal of Scientific Research, 29, 396-403.

[122] Hazim, A.S.A., Aung, M.M., Abdullah, L.C., Salleh, M.Z. and Mahmood, M.H. (2013) Production Jatropha Oil-Based Polyol via Epoxidation and Ring Opening. Industrial Crops and Products, 50, 563-567. https://doi.org/10.1016/j.indcrop.2013.08.003

[123] Satheesh Kumar, M.N., Yaakob, Z., Siti, M.S. and Abdullah, S.R.S. (2010) Synthesis of Alkydresin from Non-Edible Jatropha (Jatropha curcas L.), Seed Oil. Journal of Polymers and the Environment, 18, 539-544. https://doi.org/10.1007/s10924-010-0188-x

[124] Wieland, S., Pizzi, A., Hill, S., Grigsby, W. and Pichelin, F. (2006) The Reaction in Water of UF Resins with Isocyanates at Short Curing Times: A ${ }^{13} \mathrm{C}$ NMR Investigation. Journal of Applied Polymer Science, 100, 1624-1632.

https://doi.org/10.1002/app.23679

[125] Pechar, T.W., Sohn, S., Wilkes, G.L., Ghosh, S., Frazier, C.E., Fornof, A. and Long, T.E. (2006) Characterization and Comparison of Polyurethane Networks Prepared Using Soybean-Based Polyols with Varying Hydroxyl Content and Their Blends with Petroleum-Based Polyols. Journal of Applied Polymer Science, 101, 1432. https://doi.org/10.1002/app.23625

[126] Petrovic, Z.S., Guo, A. and Zhang, W. (2000) Structure and Properties of Polyurethanes Based on Halogenated and Non Halogenated Soy-Polyols. Journal of Polymer Science Part A: Polymer Chemistry, 38, 4062-4069. https://doi.org/10.1002/1099-0518(20001115)38:22<4062::AID-POLA60>3.0.CO;2$\underline{\mathrm{L}}$

[127] Denis, G. (2009) Process for Improving the Hydrolysis Resistance of Urethane Elastomer. United States Patent US 20090054600.

[128] Ionescu, M. (2005) Chemistry and Technology of Polyols for Polyurethanes. Rapr Technology Limited, Shropshire.

[129] Cognard, P. (2005) Handbook of Adhesives and Sealants: Basic Concepts and High Tech Bonding. Elsevier Limited, Oxford.

[130] Arnoldus, R. (1990) Waterborne Coating, Surface Coating. In: Wilson, A.D., Nicholson, J.W. and Prosser, H.J., Eds., Surface Coating, Vol. 3, Elsevier Applied Science, New York, 93-127.

[131] Ang, K.P., Lee, C.S., Cheng, S.F. and Chuah, C.H. (2014) Synthesis of Palm Oil-Based Polyester Polyol for Polyurethane Adhesive Production. Journal of Applied Polymer Science, 131. https://doi.org/10.1002/app.39967

[132] Radojčić, D., Ionescu, M., Zoran, S. and Petrović, Z.S. (2013) Novel Potentially Biodegradable Polyurethanes from Bio-Based Polyols. Contemporary Materials, 4, 9-21.

[133] Miao, S., Zhang, S., Su, Z. and Wang, P. (2010) A Novel Vegetable Oil-Lactate Hybrid Monomer for Synthesis of High-Tg Polyurethanes. Polymer Chemistry, 48, 243-250. https://doi.org/10.1002/pola.23759

[134] Wang, Z., Yu, L., Ding, M., Tan, H., Li, J. and Fu, Q. (2011) Preparation and Rapid Degradation of Nontoxic Biodegradable Polyurethanes Based on Poly(Lactic Ac- 
id)-Poly(Ethylene Glycol)-Poly(Lactic Acid) and Llysine Diisocyanate. Polymer Chemistry, 2-3, 601. https://doi.org/10.1039/C0PY00235F

[135] Ottey, F.H., Benett, F.H., Zagoren, B.L. and Mehltretter, C.L. (1965) Preparation and Properties of Glycol Glycoside Polyethers for Rigid Urethane Foams. Industrial and Engineering Chemistry Product Research and Development, 4, 224-227.

https://doi.org/10.1021/i360016a002

[136] Cocks, L.V. and Van, R.C. (1976) Laboratory Handbook for Oil and Fat Analysis. Academic Press, London.

[137] Pan, X. and Saddler, J.N. (2013) Effect of Replacing Polyol by Organosolv and Kraft Lignin on the Property and Structure of Rigid Polyurethane Foam. Biotechnology for Biofuels, 6, Article 12. https://doi.org/10.1186/1754-6834-6-12

[138] Lora, J. (2008) Industrial Commercial Lignins: Sources, Properties and Applications. In: Belgacem, M.N. and Gandini, A., Eds., Monomers, Polymers and Composites from Renewable Resources, Elsevier, Amsterdam, 225-241. https://doi.org/10.1016/B978-0-08-045316-3.00010-7

[139] Duval, A. and Lawoko, M. (2014) A Review on Lignin-Based Polymeric, Micro and Nano-Structured Materials. Reactive and Functional Polymers, 85, 78-96. https://doi.org/10.1016/j.reactfunctpolym.2014.09.017

[140] Kandula, M., Schwenke, T., Friebel, S. and Salthammer, T. (2015) Effect of Ball Milling on Lignin Polyesterification with E-Caprolactone. Holzforschung, 69, 297-302. https://doi.org/10.1515/hf-2014-0053

[141] Braun, J.L., Holtman, K.M. and Kadla, J.F. (2005) Lignin-Based Carbon Fibers: Oxidative Thermo Stabilization of Kraft Lignin. Carbon, 43, 385-394. https://doi.org/10.1016/j.carbon.2004.09.027

[142] Norberg, I., Nordström, Y., Drougge, R., Gellerstedt, G. and Sjöholm, E. (2013) A New Method for Stabilizing Softwood Kraft Lignin Fibers for Carbon Fiber Production. Journal of Applied Polymer Science, 128, 3824-3830. https://doi.org/10.1002/app.38588

[143] Gordobil, O., Delucis, R., Egüés, I. and Labidi, J. (2015) Kraft Lignin as Filler in PLA to Improve Ductility and thermal Properties. Industrial Crops and Products, 72, 46-53. https://doi.org/10.1016/j.indcrop.2015.01.055

[144] Schorr, D., Diouf, P.N. and Stevanovic, T. (2014) Evaluation of Industrial Lignins for Biocomposites Production. Industrial Crops and Products, 52, 65-73. https://doi.org/10.1016/j.indcrop.2013.10.014

[145] Spiridon, I., Leluk, K., Resmerita, A.M. and Darie, R.N. (2015) Evaluation of PLA-Lignin Bioplastics Properties before and after Accelerated Weathering. Composites Part B: Engineering, 69, 342-349.

https://doi.org/10.1016/j.compositesb.2014.10.006 